\title{
Anti-Inflammatory, Antioxidant and Anti-Angiogenic Activities of Diosgenin Isolated from Traditional Medicinal Plant, Costus speciosus (Koen ex.Retz.) Sm
}

\author{
Samy Selim ${ }^{\mathrm{a}, \mathrm{c}^{*}}$, Soad Al Jaouni ${ }^{\mathrm{a}}$ \\ ${ }^{a}$ Department of Clinical Laboratory Sciences, College of Applied Medical Sciences, Aljouf \\ University, Sakaka, P.O. 2014, Saudi Arabia \\ ${ }^{b}$ Scientific Chair of YAJ Prophetic Medicine Application, College of Medicine, King \\ Abdulaziz University, P.O. Box 80215, Jeddah 21589, Saudi Arabia \\ ${ }^{c}$ Microbiology and Botany Department, Faculty of Science, Suez Canal University, Ismailia, \\ P.O. 41522, Egypt \\ * Corresponding author. Department of Clinical Laboratory Sciences, College of Applied \\ Medical Sciences, Aljouf University, P.O. 2014 Sakaka, Saudi Arabia \\ *Corresponding Author: sadomm2003@yahoo.com
}

Costus speciosus is an important medicinal plant widely used in several indigenous medicinal formulations. The present study was conducted to evaluate the in vitro antiinflammatory, antioxidant and anti-angiogenic activities of diosgenin isolated from $C$. speciosus. The diosgenin isolated from $C$. speciosus by HPTLC and study its biological activities by different protocols. The results demonstrated that LPS stimulated TNF- $\alpha$ generation in RAW 264.7 macrophages culture supernatant up to 3.7-fold of the control and that sample treatment $(50 \mu \mathrm{g} / \mathrm{mL})$ resulted in a highly significant inhibitory effect on LPSstimulated TNF- $\alpha(\mathrm{P}<0.01)$ in a similar manner to methotrexate inhibitory effect. The tested sample possessed an effective antioxidant scavenging affinity against DPPH radicals as compared with the standard antioxidant activity of vitamin C. The results presented here may suggest that diosgenin isolated from $C$. speciosus possess anticancer, apoptotic and inhibitory effects on cell proliferation.

Key words: Anti-inflammatory; antioxidant; anti-angiogenic; Diosgenin; C. speciosus 


\section{Supplementary Results}

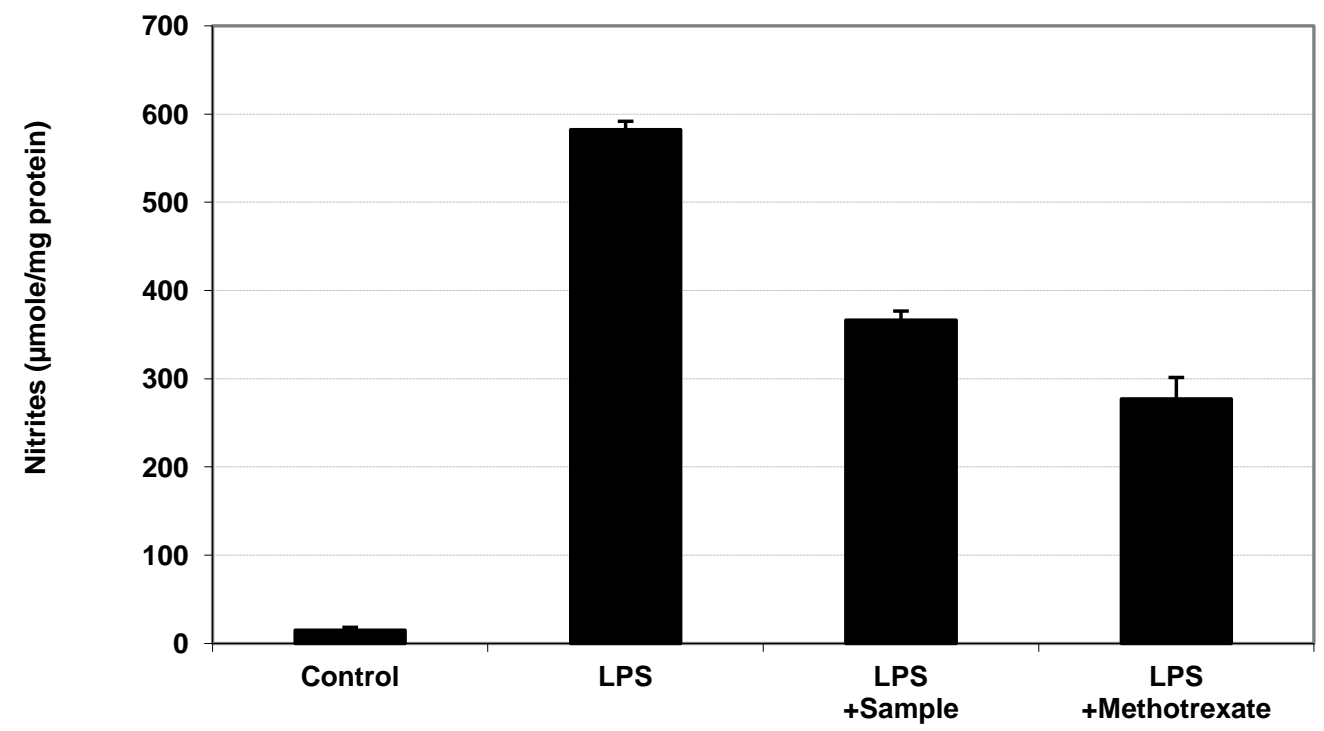

Figure S1. The level of nitrites in RAW 264.7 cells lysate after the treatment with the samples (50 $\mu \mathrm{g} / \mathrm{mL})$ and LPS for $24 \mathrm{~h}$ compared LPS treated cells, as measured by Griess assay. The data are presented as nmole/mg protein (mean $\pm \mathrm{SE}$ )

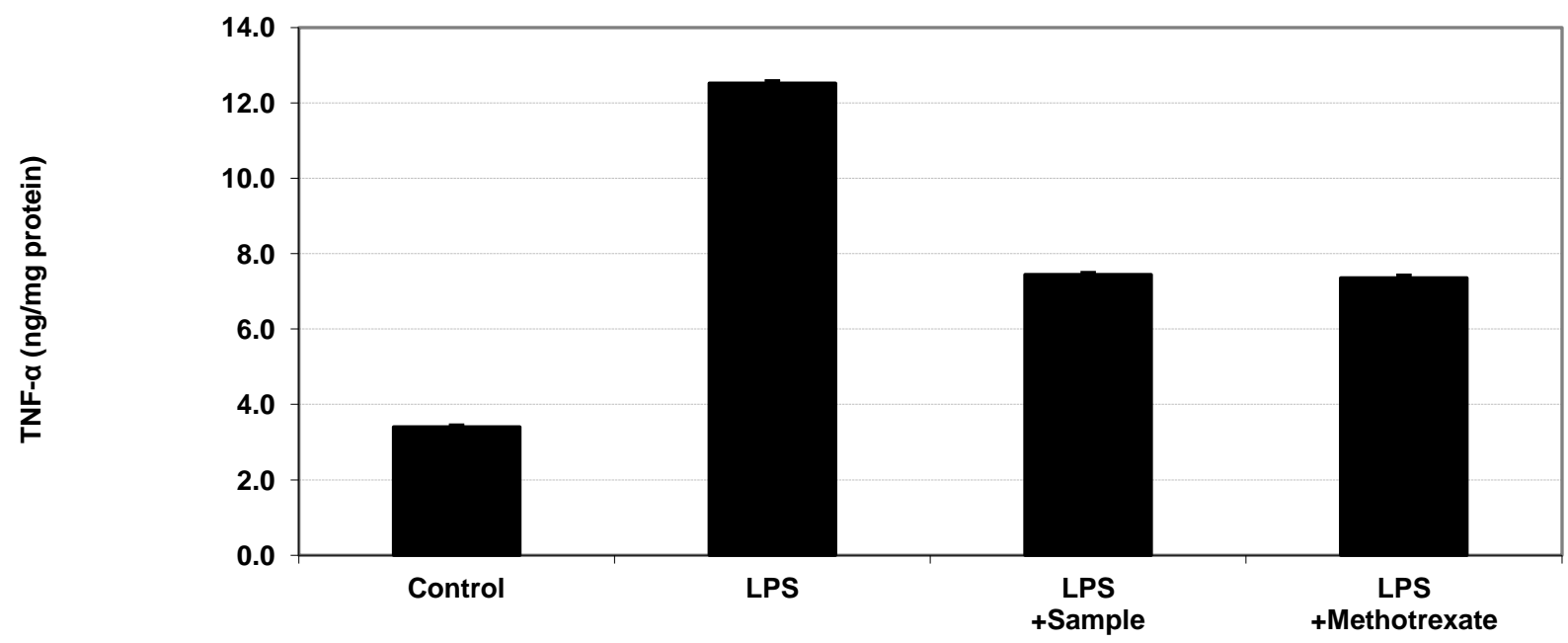

Figure S2. The level of TNF- $\alpha$ protein in RAW 264.7 macrophages culture supernatant after the treatment with the samples $(50 \mu \mathrm{g} / \mathrm{mL})$ and LPS for $24 \mathrm{~h}$ compared LPS treated cells, as measured by ELISA assay. The data are presented as $\mathrm{ng} / \mathrm{mg}$ protein (mean $\pm \mathrm{SE}$ ) 


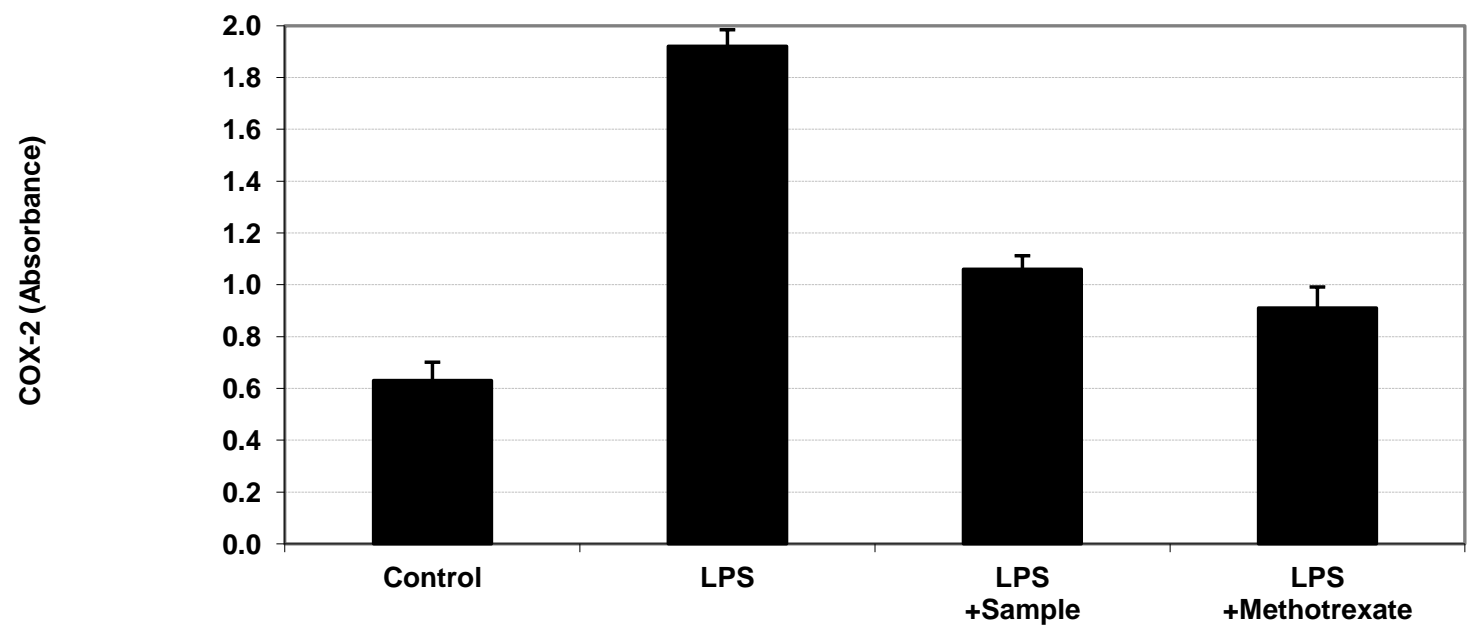

Figure S3. The level of COX-2 protein in RAW 264.7 macrophages lysate after the treatment with the samples $(50 \mu \mathrm{g} / \mathrm{mL})$ and LPS for $24 \mathrm{~h}$ compared LPS treated cells, as measured by ELISA assay. The data are presented as absorbance (mean $\pm \mathrm{SE}$ ).

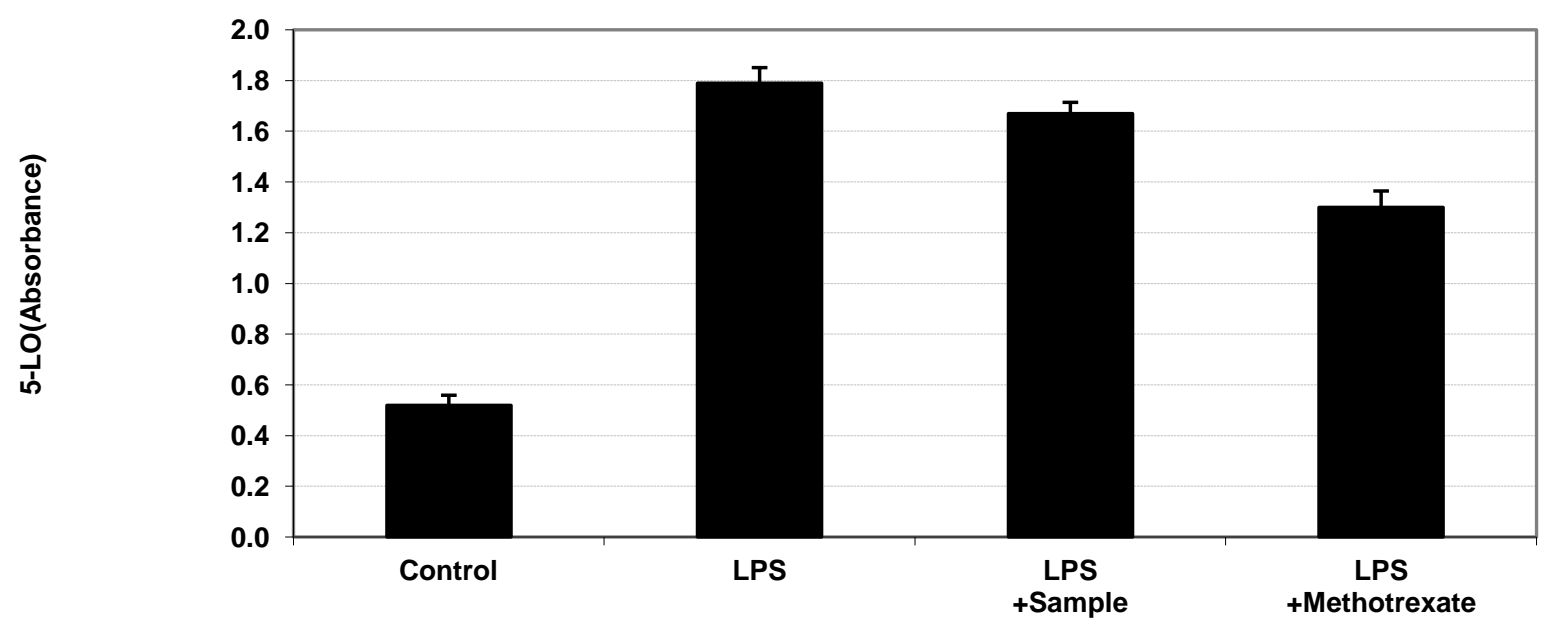

Figure S4. The level of 5-LO protein in RAW 264.7 macrophages lysate after the treatment with the samples $(50 \mu \mathrm{g} / \mathrm{mL})$ and LPS for $24 \mathrm{~h}$ compared LPS treated cells, as measured by ELISA assay. The data are presented as absorbance (mean $\pm \mathrm{SE}$ ) 


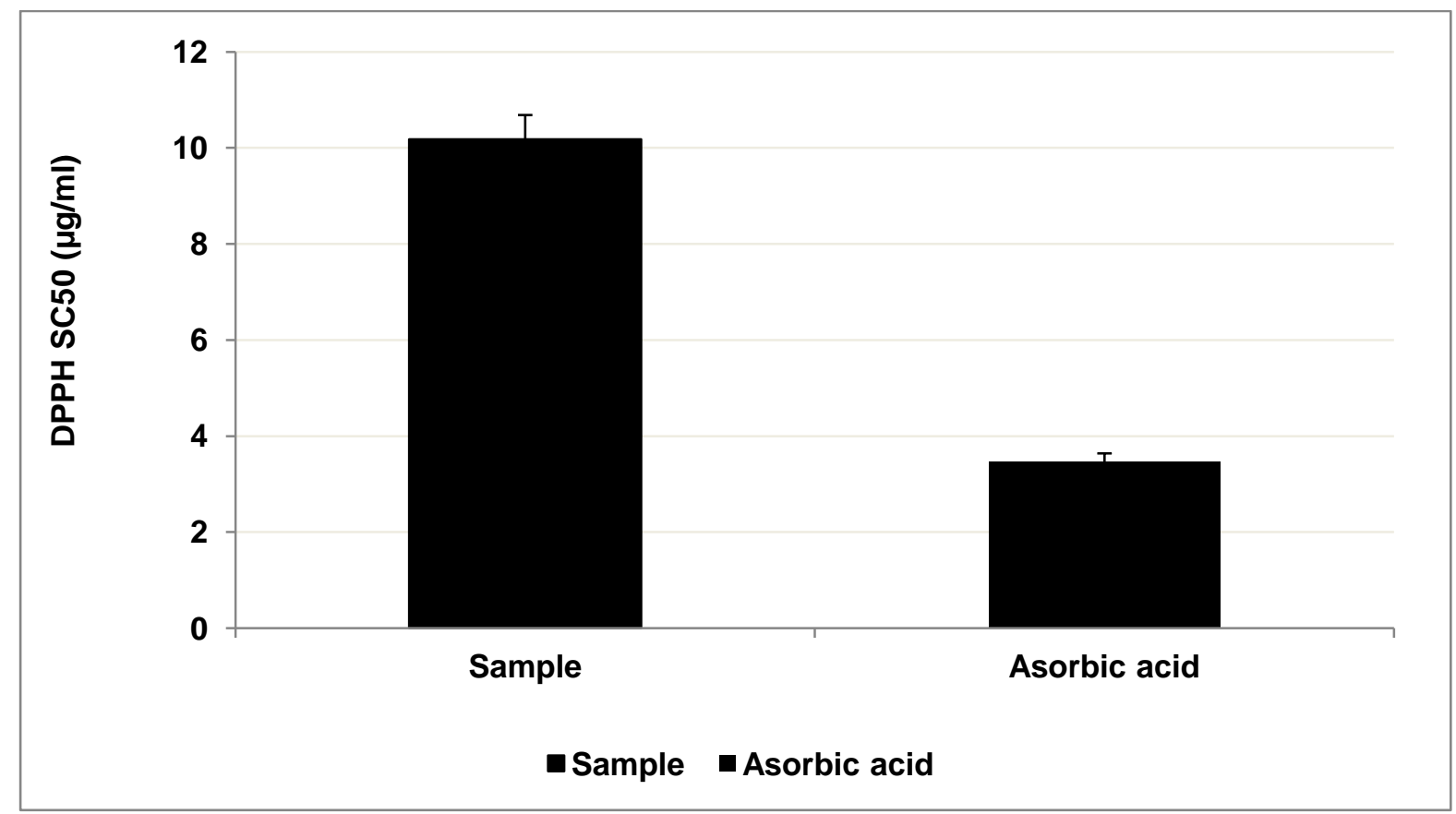

Figure S5. Antioxidant activity of tested sample against DPPH radicals as compared with ascorbic acid activity. DPPH assay is a non-cellular colorimetric assay. The data are presented as $\mathrm{SC}_{50}(\mu \mathrm{g} / \mathrm{mL}$, mean $\pm \mathrm{SE})$.

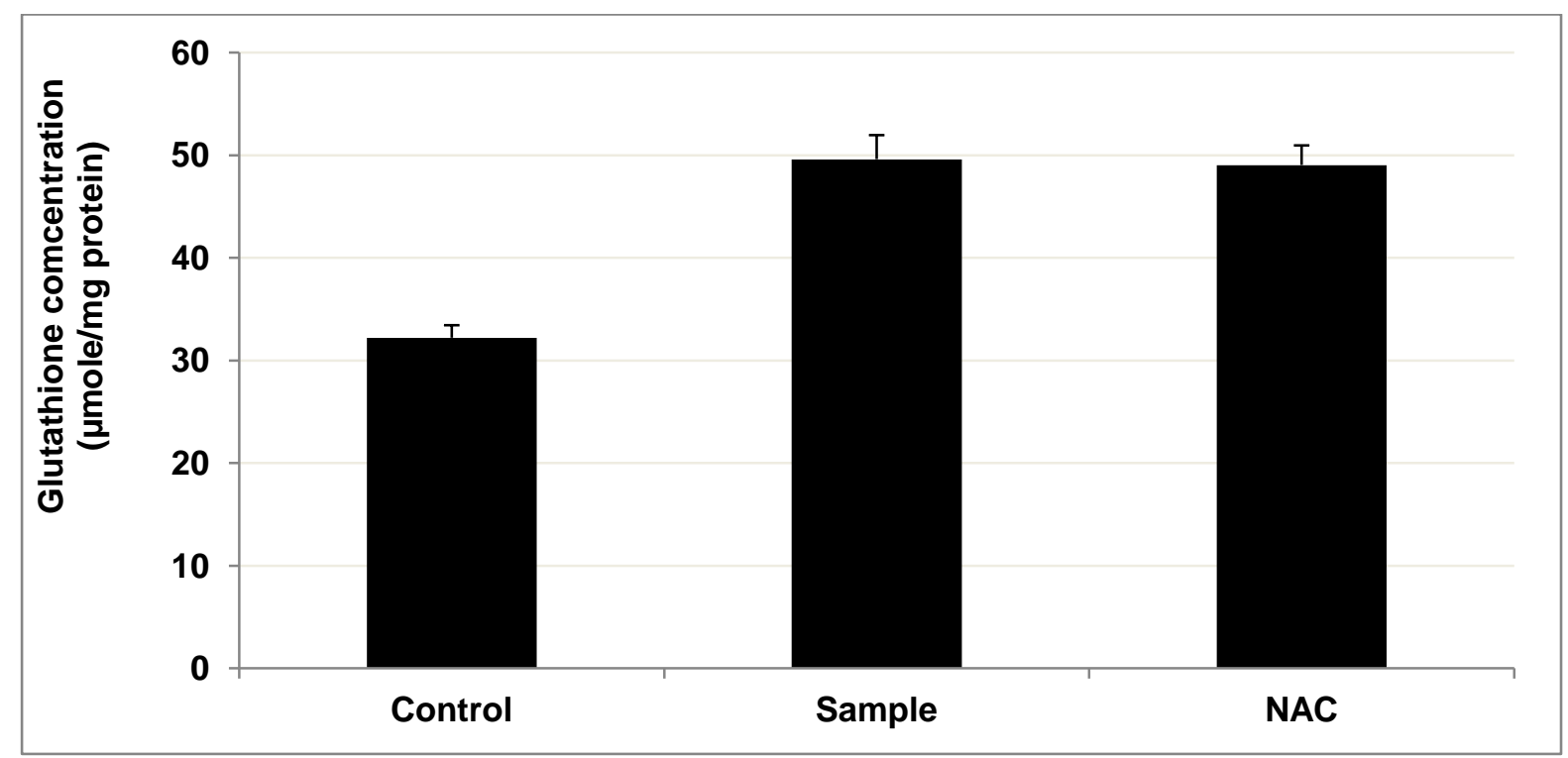

Figure S6. The level of glutathione protein in Hep-G2 cell lysate after the treatment with the tested sample $\left(30 \%\right.$ of the $\left.\mathrm{IC}_{50}\right)$ for $24 \mathrm{~h}$ compared NAC-treated cells $(100 \mu \mathrm{g} / \mathrm{mL})$, as measured by Ellman's assay. The data are presented as $\mu$ mole/mg protein (mean $\pm \mathrm{SE}$ ). 


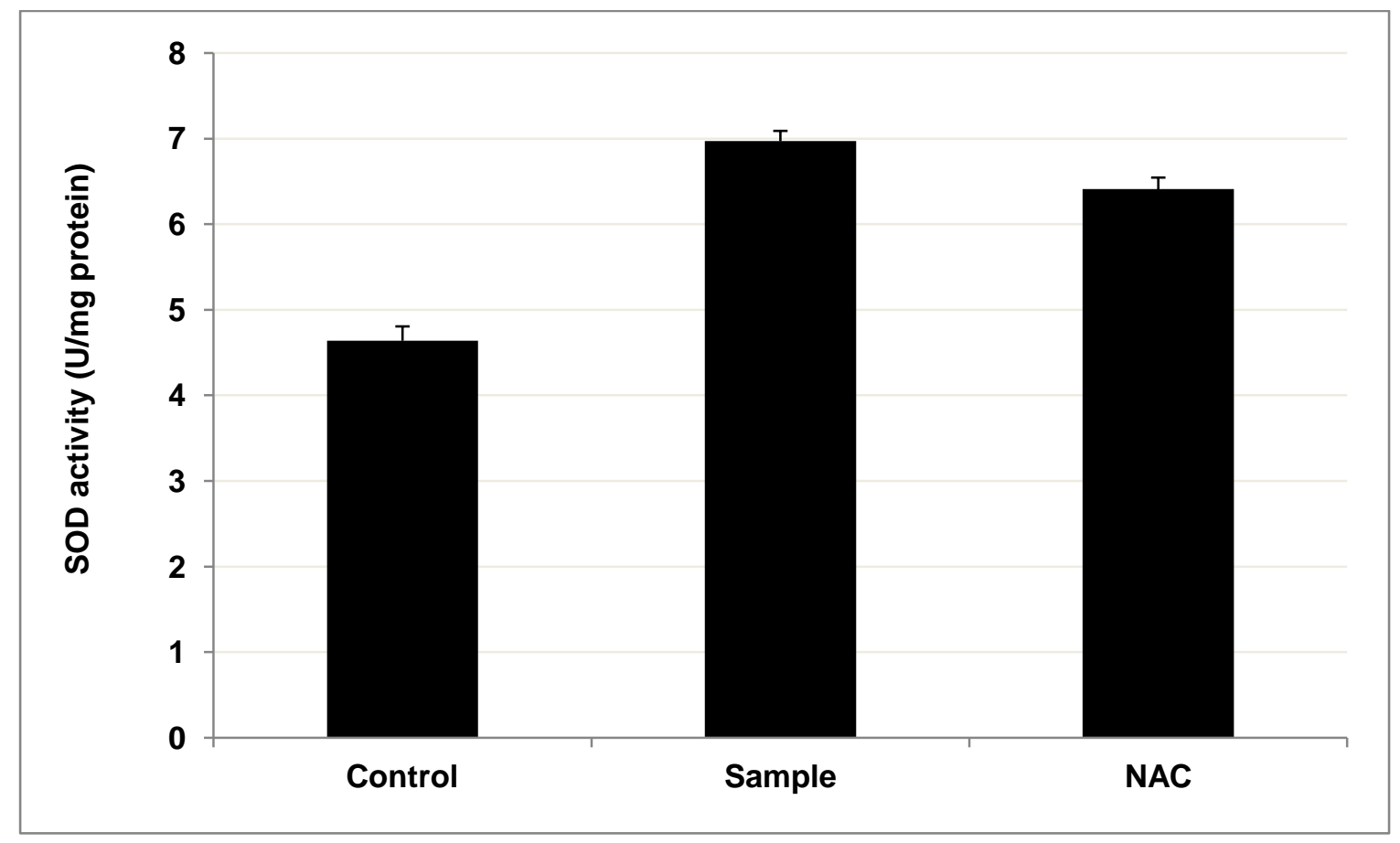

Figure S7. The activity of superoxide dismutase enzyme in Hep-G2 cell lysate after the treatment with the tested sample $\left(30 \%\right.$ of the $\mathrm{IC}_{50}$ ) for $24 \mathrm{~h}$ compared NAC-treated cells (100 $\mu \mathrm{g} / \mathrm{mL}$ ), as measured by colorimetric assay. The data are presented as U/mg protein (mean $\pm \mathrm{SE})$.

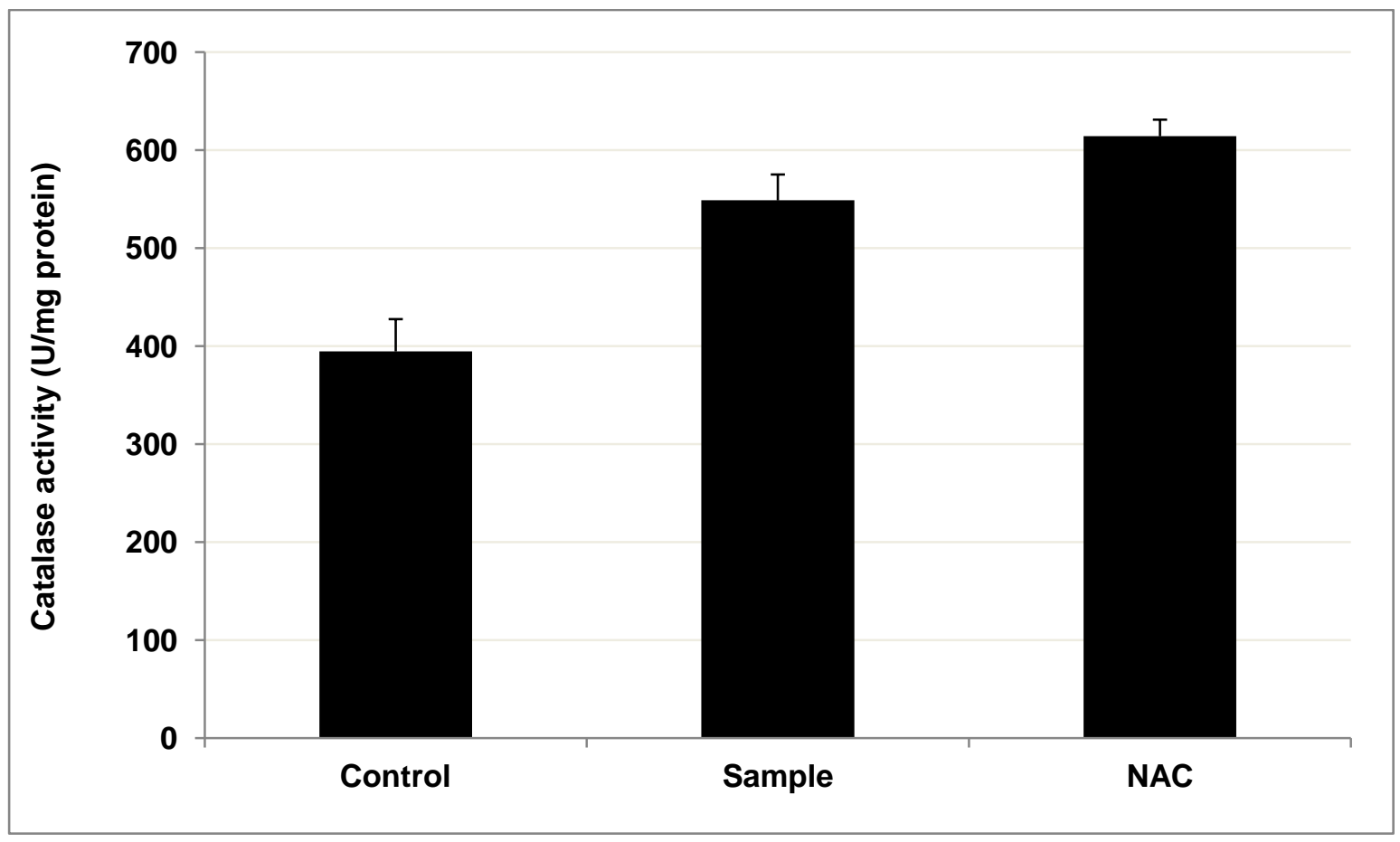

Figure S8. The activity of catalase enzyme in Hep-G2 cell lysate after the treatment with the tested sample $\left(30 \%\right.$ of the $\left.\mathrm{IC}_{50}\right)$ for $24 \mathrm{~h}$ compared NAC-treated cells $(100 \mu \mathrm{g} / \mathrm{mL})$, as measured by colorimetric assay. The data are presented as $\mathrm{U} / \mathrm{mg}$ protein (mean $\pm \mathrm{SE}$ ) 


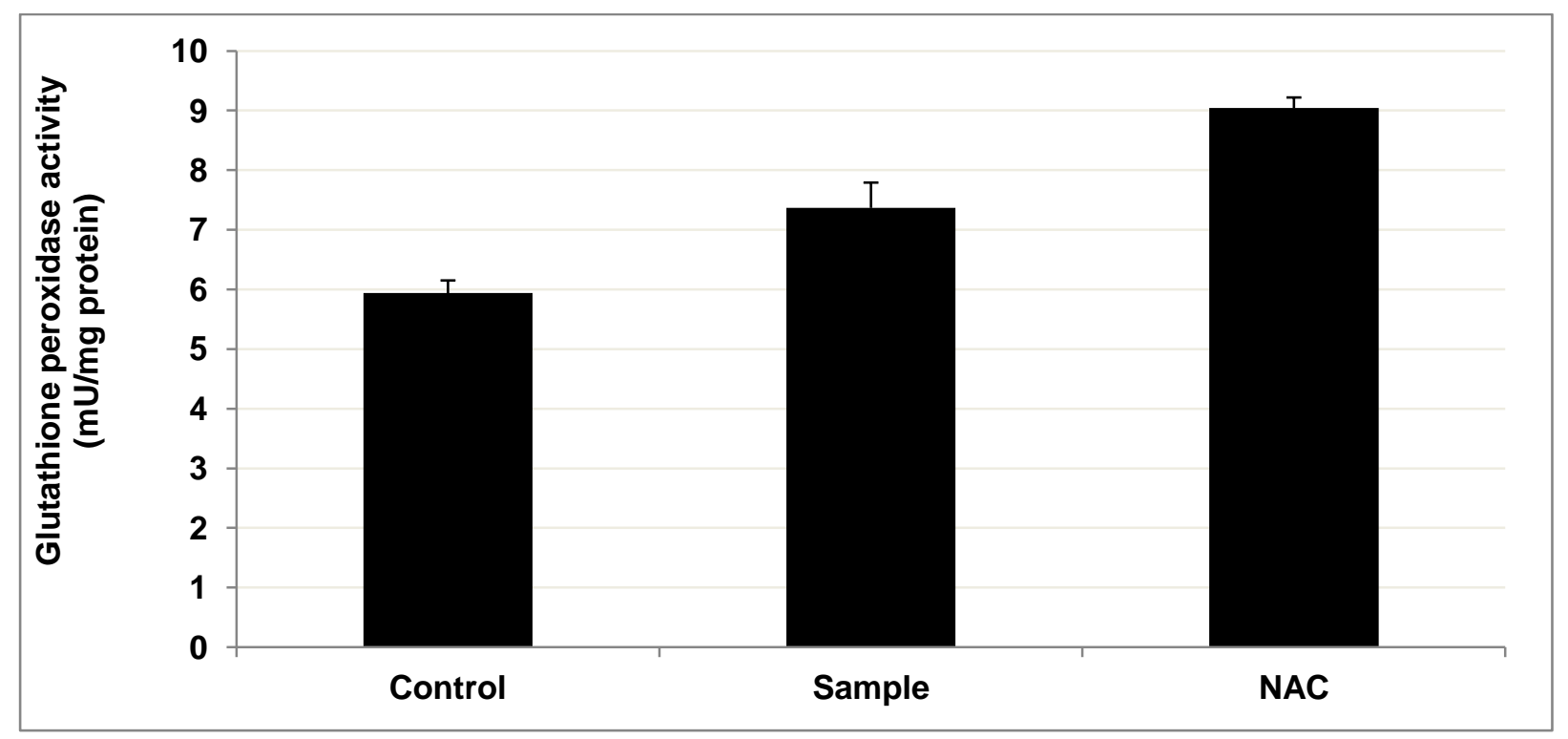

Figure S9. The activity of glutathione peroxidase enzyme in Hep-G2 cell lysate after the treatment with the tested sample $\left(30 \%\right.$ of the $\left.\mathrm{IC}_{50}\right)$ for $24 \mathrm{~h}$ compared NAC-treated cells (100 $\mu \mathrm{g} / \mathrm{mL}$ ), as measured by colorimetric assay. The data are presented as $\mathrm{mU} / \mathrm{mg}$ protein (mean $\pm \mathrm{SE})$.

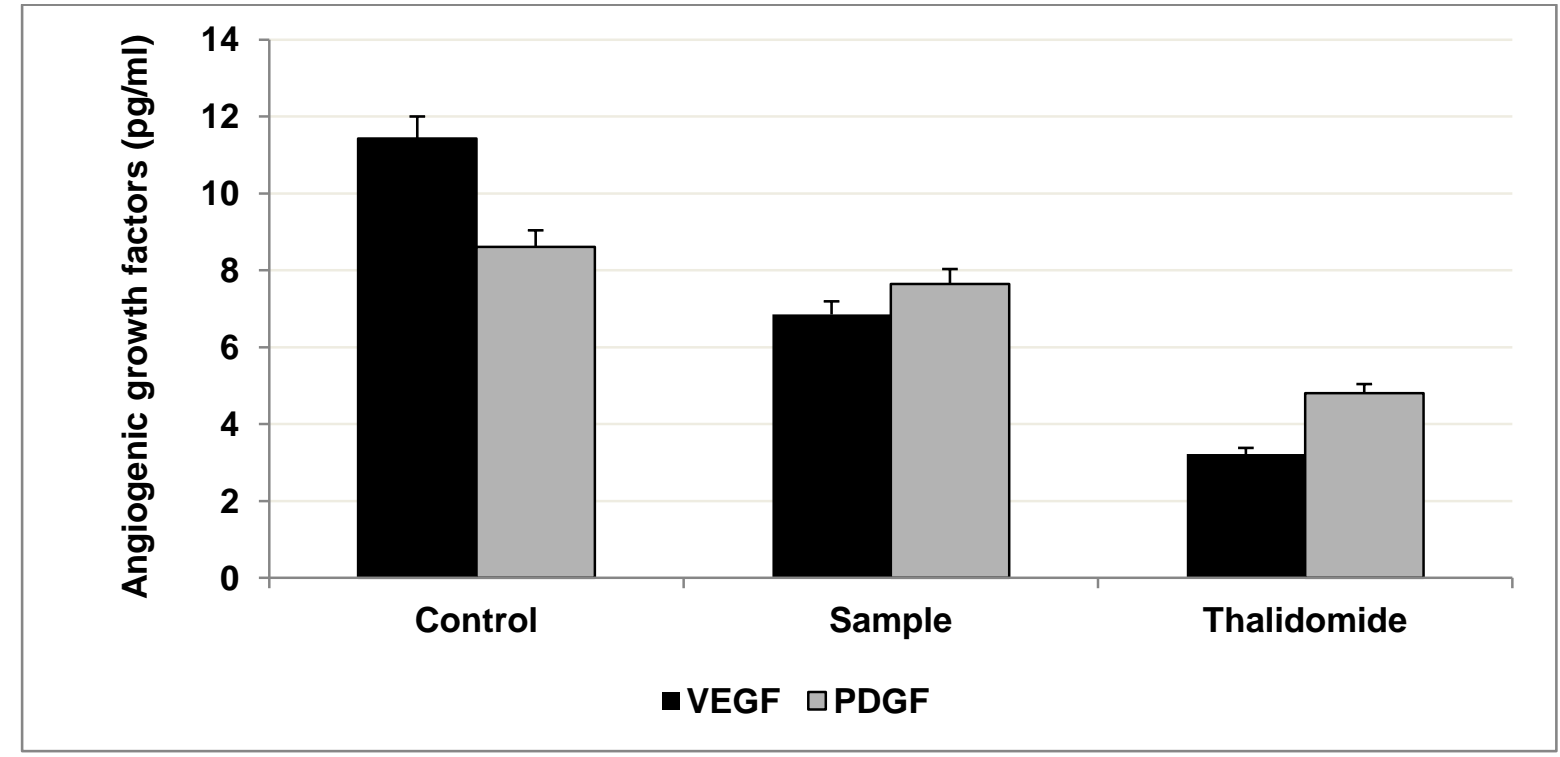

Figure S10. The concentration of VEGF and PDGF in MCF-7 cell lysate after the treatment with the tested sample (30\% of the IC50) for $24 \mathrm{~h}$ compared thalidomider-treated cells (100 $\mu \mathrm{g} / \mathrm{mL}$ ), as measured by ELISA. The data are presented as $\mathrm{pg} / \mathrm{mL}$ (mean $\pm \mathrm{SE}$ ). 


\section{$\underline{\text { Supplementary Materials }}$}

\section{Experimental}

\section{Chemical reagents and cells}

Diosgenin was obtained from Sigma-Aldrich Co. LLC. (MO, USA) and dissolved in ethanol. All cell maintaining materials was obtained from Cambrex, BioScience (Copenhagen, Denmark), while all other fine chemicals were from Sigma-Aldrich (CT, USA).

\section{Raw material and HPTLC analysis}

C. speciosus was procured from a fixed vendor in the local market of Al Jouf, KSA. Specimens were identified at the Aljouf University (Aljouf, Saudi Arabia) and voucher specimen (No. 13) was deposited at the Herbarium of the Department in the cited university. Consents and all ethical relevant procedures were designed according to Aljouf University bioethics committee guidelines. Dried tuber powder (5 gms) was treated with slightly modified method described by Drapeau et al. (1986). Samples were hydrolyzed in $150 \mathrm{~mL}$ of refluxing $20 \% \mathrm{H}_{2} \mathrm{SO}_{4}$ in $70 \%$ isopropanol for $8 \mathrm{~h}$. The extract was filtered and extracted with hexane $(50 \mathrm{~mL} \times 3)$. The three hexane extracts were combined and rinsed thrice times with $5 \%$ alkali and then rinsed thrice with distilled water. The extract was then passed through a column of $\mathrm{Na}_{2} \mathrm{SO}_{4}$ to eliminate any remaining water. The samples were concentrated to dryness by evaporating the solvent at $40^{\circ} \mathrm{C}$ in a Rotary evaporator. The dried crude extract was solubilized in $0.5 \mathrm{~mL}$ of chloroform prior to the quantitative determination of diosgenin by thin layer chromatography. To begin the analysis, mobile phase T:EA:FA:GAA in the ratio 2:1:1:0.75 v/v reported by Kshirsagar et al. (2008) was preferred.

\section{Anti-inflammatory activity}

Nitrite accumulation was used as an indicator of NO production using a microplate assay based on the Griess reaction (Green et al. 1982). A standard curve relating NO in $\mu \mathrm{m}$ to the absorbance is constructed, from which the NO level in the cell homogenate is computed by interpolation. The levels of Tumor necrosis factor (TNF- $\alpha$ ), cyclooxygenase-2 (COX-2) and 5-lipooxygenase (5-LO) were measured in the cell lysate by ELISA.

\section{Estimation of Antioxidant Activity}


In a flat bottom 96 well-microplate, a total test volume of $200 \mu 1$ was used. In each well, $20 \mu 1$ of different concentrations of tested sample $(0-40 \mu \mathrm{g} / \mathrm{mL}$ final concentration $)$ of tested sample were mixed with $180 \mu \mathrm{l}$ of ethanolic DPPH were mixed and incubated for $30 \mathrm{~min}$ at $37^{\circ} \mathrm{C}$.Triplicate wells were prepared for each concentration and the average was calculated. The total thiol concentrations (mainly GSH) were measured by an enzymatic cycling procedure based on the oxidation of thiols by 5,5'-dithiobis- (2-nitrobenzoic acid) (DTNB) and their reduction by NADPH in the presence of glutathione reductase (GR) (Griffith 1981). The SOD activity was estimated in macrophages lysate using the nitroblue tetrazolium/phenazine methosulfate (NBT/PMS) assay (Ewing \& Janero 1995). Cell lysates were assayed to measure CAT activity at $25^{\circ} \mathrm{C}$, based on the disappearance of $\mathrm{H}_{2} \mathrm{O}_{2}$ at $240 \mathrm{~nm}$, but with some modifications for the detection in 96 well-microplates (Aebi 1983). GPx activity was determined by quantifying the rate of oxidation of GSH by cumene hydroperoxide as catalyzed by GPx present in the cell lysate samples (Lawrence \& Burk 1976).

\section{Anti-angiogenic activity}

The level of vascular epidermal growth factor (VEGF) and platelets-derived growth factor (PDGF) in supernatant of cell lysates was quantified using Sandwich ELISA as described by Adolf and Apfler (1991).

\section{Statistical Analysis}

Data were statistically analyzed using IBM computer supplied with Statistical Package for Social Scientists (SPSS) 10.00 for windows (SPSS Inc., Chicago, IL., USA). The student's unpaired t-test as was used to detect the statistical significance. $\mathrm{P}$ value was considered insignificant if more than 0.05 .

\section{References}

Adolf GR, Apfler I. 1991. A monoclonal antibody-based enzyme immunoassay for quantitation of human tumor necrosis factor binding protein I, a soluble fragment of the $60 \mathrm{kDa}$ TNF receptor, in biological fluids. J Immunol Methods. 143(1):127-36.

Aebi HE. 1983. Catalase. In: Methods of enzymatic analysis, HU Bergmeyer ed., Verlag Chemie, Weinheim, 273-82.

Carmeliet P, Jain RK. 2000. Angiogenesis in cancer and other diseases. Nature 407: 249-257. 
Drapeau D, Sauvaire Y, Blanch HW, Wilke CR. 1986. Improvement of diosgenin yield from Dioscorea deltoidea plant cell culture by use of a non-traditional hydrolysis method. Planta Med. 6:474-478.

Ewing JE, Janero DR. 1995. Microplate superoxide dismutase assay employing nonenzymatic superoxide generator. Anal. Biochem. 232:243-8.

Green LC, Wagner DA, Glogowski J, Skipper PL, Wishnok JS, Tannenbaum SR. 1982. Analysis of nitrate, nitrite and $(15 \mathrm{~N})$ nitrate in biological fluids. Anal. Biochem. 126: $131-138$.

Griffith OW. 1981. Determination of glutathione and glutathione disulphide using glutathione reductase and 2-vinylpyridine. Anal. Biochem. 106:207-12.

Kshirsagar VB, Deokate UA, Bharkad VB, Khadabadi SS. 2008. HPTLC method development and validation for the simultaneous estimation of diosgenin and Levodopa in marketed formulation. Asian J. Research Chem. 1:36-39.

Lawrence RA, Burk RF. 1976. Glutathione peroxidase activity in selenium-deficient rat liver. Biochem. Biophys. Res. Commun. 71:952-8. 